\title{
Potential of Zanthoxylum leprieurii as a source of active compounds against drug resistant Mycobacterium tuberculosis
}

\author{
Lydia Bunalema1*, Ghislain Wabo Fotso ${ }^{2}$, Paul Waako', John Tabuti ${ }^{3}$ and Samuel O. Yeboah ${ }^{4}$
}

\begin{abstract}
Background: Tuberculosis (TB) is still a global health problem mainly due to development of resistance and co-infection with the Human immune Virus (HIV). Treatment of multi and extensively drug resistant TB requires use of second line drugs which are less efficacious, expensive and very toxic. This has necessitated a need to search for new treatment regimens especially from medicinal plants. Zanthoxylum leprieurii, a plant species from Rutaceae is used locally in the treatment of tuberculosis in Uganda. The aim of the study was to isolate, identify and characterize bio active compounds from Z. leprieurii stem bark with antimycobacterial activity.

Methods: Crude extracts, fractions and compounds from air dried stem bark of Z. leprieurii were tested against pan sensitive (H37rv), isoniazid resistant (TMC 301) and rifampicin resistant (TMC 331) strains of M. tuberculosis using micro plate alamar blue assay. Isolation of active compounds was done by using column chromatography and thin layer chromatography. They were analysed using nuclear magnetic resonance spectroscopy and mass spectroscopy.

Results: The methanol extract had minimum inhibitory concentrations (MIC) of 47.5, 75.3 and $125.0 \mu \mathrm{g} / \mathrm{ml}$ on the pan sensitive strain, rifampicin resistant and isozianid resistant strains of $M$. tuberculosis respectively. The chloroform extract had MIC values of $260 \mu \mathrm{g} / \mathrm{ml}$ agnaist the pan sensitive strain and $156 \mu \mathrm{g} / \mathrm{ml}$ on the rifampicin resistant strain. Of the sixteen fractions from the methanol extract, fraction $Z_{4}(M I C=6.3 \mu \mathrm{g} / \mathrm{mL}, 23.0 \mu \mathrm{g} / \mathrm{mL}, 11.7 \mu \mathrm{g} / \mathrm{mL})$ and $Z a_{6}(M I C=11.7 \mu \mathrm{g} / \mathrm{mL}$ $31.2 \mu \mathrm{g} / \mathrm{ml}, 31.2 \mu \mathrm{g} / \mathrm{ml}$ ) were the most active. Three acridone alkaloids; hydroxy-1, 3-dimethoxy-10-methyl-9-acridone (1), 1-hydroxy-3-methoxy-10-methyl-9-acridone (2) and 3-hydroxy-1, 5, 6-trimethoxy-9-acridone (3) were isolated from $\mathrm{Za}_{4}$ and $\mathrm{Za}_{6}$. The MIC of compound 3 was found to be $5.1 \mu \mathrm{g} / \mathrm{ml}, 4.5 \mu \mathrm{g} / \mathrm{ml}$ and $3.9 \mu \mathrm{g} / \mathrm{ml}$ on H37rv, TMC 331 and TMC 301 while that of 1 was found to be $1.5 \mu \mathrm{g} / \mathrm{ml}, 8.3 \mu \mathrm{g} / \mathrm{ml}$ and $3.5 \mu \mathrm{g} / \mathrm{ml}$ respectively.

Conclusion: The results of this study suggest that $Z$. leprieurii is active on resistant strains of $M$. tuberculosis and could be a potential source of new leads against resistant tuberculosis. It also verifies the local use of the plant in treatment of tuberculosis.
\end{abstract}

Keywords: Zanthoxylum leprieurii, Tuberculosis, Isolation, Acridone alkaloids, Antimycobacterial activity

\section{Background}

Mycobacterium tuberculosis, the bacillus that causes tuberculosis (TB), is one of the leading causes of illness and death worldwide, accounting for 9.6 million new cases and 1.5 million deaths per year [1]. Africa carries the most severe TB burden with a prevalence of 281 cases per 100,000 individuals compared to the global

\footnotetext{
*Correspondence: blydia@chs.mak.ac.ug; blydia2002@yahoo.com 'Department of Pharmacology and Therapeutics, College of Health Sciences, Makerere University, P.O Box 7072, Kampala, Uganda

Full list of author information is available at the end of the article
}

average of 133/100, 000 [2]. Uganda, one of the high TB burden countries, reports approximately 166 new cases per 100,000 people [3]. The high TB burden is attributed to Human Immune Virus (HIV) co-infection in addition to development of multi- and extensively drug resistant strains (MDR and XDR) of TB [3]. Worldwide, MDR TB was reported to account for $5 \%$ of all new tuberculosis cases [4] of which $9 \%$ was caused by XDR-TB [5].

Treatment of resistant strains of MDR TB presents a challenge globally because it involves use of more than three drugs for a long period which results in non 
adherence and development of even more resistant strains [6]. While new drugs like bedaquiline and delamanid have recently been discovered and approved for use in MDR TB [7], they are expensive and mostly unavailable in poor resource countries. Furthermore, discovery of these new drugs took approximately 40 years since the last new anti TB drug was introduced. This slow pace in drug development in addition to the rapid emergence and spread of resistant TB calls for continuous search for new agents that are effective against resistant $M$. tuberculosis.

Medicinal plants have long been used for treatment of different ailments in local communities [8]. As such, drugs like chloroquine, artemisinin derivatives and morphine have been derived from different plant sources [9]. Zanthoxyllum contains about 549 species distributed worldwide; making it the largest genus in Rutaceae [10] Zanthoxyllum leprieurii, a plant species belonging to the same family, is traditionally used in the treatment of HIV/ AIDS, malaria, urinary infections, rheumatic pain and is used as an antiseptic in Africa [11, 12]. In addition, it is used by communities in Uganda for management of TB and cough related infections $[13,14]$. Pharmacological assessment of $Z$. leprieurii could potentially lead to the discovery of new anti-TB agents as well as verify its use among local people in Uganda communities. The aims of the study were to; assess the anti mycobacterial activity of $Z$. leprieurii, to isolate compounds from $Z$. leprieurii and to determine the antimycobacterial activity of the isolated compounds against a pan sensitive, rifampicin resistant and isoniazid resistant strains of $M$. tuberculosis.

\section{Methods}

\section{Preparation of plant extract}

Stem bark of $Z$. leprieurii Guill. \& Perr (locally called 'Munyenye' in luganda) was collected from Mpigi District in Central Uganda ( $\left.0^{\circ} 13^{\prime} 38.4708^{\prime \prime} \mathrm{N} \mathrm{32^{ \circ }} 19^{\prime} 29.7264^{\prime \prime} \mathrm{E}\right)$. With the help of a botanist (Paul Segawa from Makerere University Herbarium), the plant was identified and voucher specimen indexed as BL 030 was deposited at the Makerere University Herbarium. The powdered plant material (500 g) was weighed and soaked separately in methanol $(1000 \mathrm{ml})$ and chloroform $(1000 \mathrm{ml})$ for four days with occasional shaking. The filtrates were concentrated under reduced pressure using a rotary evaporator to give $13.25 \mathrm{~g}$ and $15.48 \mathrm{~g}$ of methanol and chloroform crude extracts respectively.

\section{Mycobacterial testing \\ Strains}

Three preserved strains of $M$. tuberculosis were used and they included; a rifampicin resistant strain (TMC 331/ATCC35838), an isoniazid resistant strain (TMC 301/ATCC 35820) and a pan sensitive strain $\left(\mathrm{H}_{37} \mathrm{Rv}\right)$ as a positive control. All the strains were obtained from Joint Clinical Research centre (JCRC) Kampala Uganda.

\section{Preparation of inoculums}

M. tuberculosis was grown on Middle brook 7H10 agar for three weeks and then introduced into 7H9 broth $(10 \mathrm{ml})$ supplemented with $0.2 \%(\mathrm{v} / \mathrm{v})$ glycerol, oleic acid, albumin, dextrose, catalase (OADC). The inoculum was incubated at $37^{\circ} \mathrm{C}$ for $24 \mathrm{~h}$. Turbidity equivalent to $0.5 \mathrm{MC}$ Farland standards $\left(1.5^{*} 10^{8} \mathrm{CFU}\right)$ were prepared using a nephlometer.

\section{Preparation of drugs and plant extracts}

The plant crude extracts, fractions, pure compounds and standard drugs were prepared in either sterile distilled water or DMSO depending on their solubility. The final concentrations tested ranged from $0.024-6.250 \mu \mathrm{g} / \mathrm{ml}$, $1.9-500 \mu \mathrm{g} / \mathrm{ml}$ and $24.4-6250 \mu \mathrm{g} / \mathrm{ml}$ for compounds/ drugs, fractions and extracts respectively.

\section{Procedure}

Susceptibility testing: Micro plate alamar blue assay (MABA) was used as described by Lawal et al., (2011) [15]. Sterile distilled water $(200 \mu \mathrm{l})$ was added to all outer perimeter wells of sterile 96-well plates to minimize evaporation. The remaining wells received $100 \mu \mathrm{l}$ of $7 \mathrm{H} 9$ broth. One hundred micro liters of double concentration drug solutions were added to each of the wells in rows $B$ to $\mathrm{G}$ in column 2 and serial dilutions were made through column 10 using a multi channel pipette.

Each of the wells in rows from 2-11 were inoculated with $100 \mu \mathrm{l}$ of $M$. tuberculosis bringing the final volume to $200 \mu \mathrm{l}$ per well. The wells in column 11 were drug free containing only the inoculum and broth and these acted as negative control wells. The plates were incubated at $37{ }^{\circ} \mathrm{C}$ for $24 \mathrm{~h}$. The tests were prepared in triplicate for each of the strains used. Thirty micro liters of a freshly prepared alamar blue reagent was added to one of the control wells and further incubated at $37{ }^{\circ} \mathrm{C}$ for $24 \mathrm{~h}$. Observation of a color change indicated that there was growth. The dye was then added to all the wells and further incubated for $24 \mathrm{~h}$. The minimum inhibitory concentration (MIC) was defined as the lowest drug concentration which prevented a color change from blue to pink (Additional file 1). The bioassays were performed in a level 3 bio safety laboratory.

\section{Phytochemical testing}

The methanolic extract was subjected to silica gel column chromatography using a gradient system of $n$-hexaneAcOEt and AcOEt-MeOH as eluents. Fractions of $250 \mathrm{ml}$ each were collected and combined on the basis of their thin layer chromatography profile. Sixteen fractions $\left(\mathrm{Za}_{1}-\right.$ $\left.\mathrm{Za}_{16}\right)$ were obtained and these were again tested on 
Mycobacterium using the above method. The fractions which showed the lowest MIC values (i.e. $\mathrm{Za}_{4}$ and $\mathrm{Za}_{6}$ ) were isolated using repetitive preparative TLC to obtain compounds 1, 2 and 3. These were analyzed using intensive $1 \mathrm{D}$ and 2D nuclear magnetic resonance (NMR) spectroscopy.

\section{General experimental procedures}

Analytical and Preparative TLC were performed respectively using silica gel 60 PF254 + 366 (Merck) and silica gel 60-F254 precoated aluminum sheets (Merck). The plates were visualized under UV (254 and $366 \mathrm{~nm}$ ) and revealed by spraying with vanillin-sulphuric acid (Additional file 2). NMR spectra were recorded on Bruker DMX Avance $300 \mathrm{MHz}$ instrument equipped with an auto-tune probe and using the automation mode aided by chloroform $\left(\mathrm{CDCl}_{3}\right)$ as solvent and internal standards.

\section{Results}

Antimycobacterial activity of fractions and crude extracts The MIC values of the methanol crude extract were $47.5 \mu \mathrm{g} / \mathrm{ml}, 75.3 \mu \mathrm{g} / \mathrm{ml}$ and $125.0 \mu \mathrm{g} / \mathrm{ml}$ against the pan sensitive, rifampicin resistant and isoniazid resistant strains respectively (Table 1 ). The chloroform crude extract had MICs of $260.0 \mu \mathrm{g} / \mathrm{ml}$ and $156.3 \mu \mathrm{g} / \mathrm{ml}$ on the pan sensitive and isoniazid resistant strains respectively.

Table 1 Mean MIC values of extracts and fractions from $Z$. leprieurii on different species of M. tuberculosis

\begin{tabular}{|c|c|c|c|}
\hline & \multirow[b]{2}{*}{$\begin{array}{l}\text { Pan sensitive } \\
\text { strain H37R }\end{array}$} & \multicolumn{2}{|l|}{ MIC $(\mu \mathrm{g} / \mathrm{ml})$} \\
\hline & & $\begin{array}{l}\text { Rifampicin resistant } \\
\text { strain TMC } 331\end{array}$ & $\begin{array}{l}\text { Isoniazid resistant } \\
\text { strain TMC } 301\end{array}$ \\
\hline \multicolumn{4}{|l|}{ Crude extracts } \\
\hline Chloroform extract & 260.0 & $>6250$ & 156.3 \\
\hline Methanol extract & 47.5 & 75.3 & 125.0 \\
\hline \multicolumn{4}{|l|}{ Fractions } \\
\hline $\mathrm{Za}_{1}$ & 31.3 & 31.3 & 78.2 \\
\hline $\mathrm{Za}_{2}$ & 94.5 & 31.3 & 63.2 \\
\hline $\mathrm{Za}_{3}$ & $>500$ & 16.4 & $>500$ \\
\hline $\mathrm{Za}_{4}$ & 6.3 & 23.0 & 11.7 \\
\hline $\mathrm{Za}_{5}$ & 31.3 & 31.3 & 94.1 \\
\hline $\mathrm{Za}_{6}$ & 11.7 & 31.3 & 31.3 \\
\hline $\mathrm{Za}_{7}$ & 94.1 & 94.1 & $>500$ \\
\hline $\mathrm{Za}_{8}$ & 63.2 & 31.3 & $>500$ \\
\hline $\mathrm{Za}_{9}$ & 63.2 & $>500$ & $>500$ \\
\hline${ }^{a} Z a_{10}$ & $>500$ & $>500$ & $>500$ \\
\hline Rifampicin & 2.0 & - & 2.0 \\
\hline Isoniazid & 4.0 & 4.0 & - \\
\hline
\end{tabular}

${ }^{\mathrm{a}} \mathrm{Za}_{10}=\mathrm{Za}_{11-} \mathrm{Za}_{16}$ with $\mathrm{MIC}>500 \mathrm{ug} / \mathrm{ml}$
The methanol extract showed a relatively lower MIC value as compared to the chloroform extract.

Sixteen fractions from the methanol crude extract were further tested. The fractions that had MICs $\leq 100 \mu \mathrm{g} / \mathrm{ml}$ on all the tested strains were; $\mathrm{Za}_{1}, \mathrm{Za}_{2}, \mathrm{Za}_{3}, \mathrm{Za}_{4}$ and $\mathrm{Za}_{6}$ (Table 1). Fraction $\mathrm{Za}_{4}$ had MICs of $6 \mu \mathrm{g} / \mathrm{ml}, 23 \mu \mathrm{g} / \mathrm{ml}$ and $11.7 \mu \mathrm{g} / \mathrm{ml}$ on the pan sensitive, rifampicin resistant and isoniazid resistant strains respectively. $\mathrm{Za}_{6}$ had MICs of $11.7 \mu \mathrm{g} / \mathrm{ml}$ on the pan sensitive strain well as on resistant strains its MIC was31.2 $\mu \mathrm{g} / \mathrm{ml}$. The MIC of fractions $\mathrm{Za}_{10-16}$ was beyond the tested concentration of $500 \mu \mathrm{g} / \mathrm{ml}$.

\section{Spectral data of isolated compounds}

Three compounds, 1-3 (Fig. 1) were isolated from fractions $\mathrm{Za}_{4}$ and $\mathrm{Za}_{6}$ of the methanol extract. Their spectral data is displayed below (Additional file 3):

Compound 1: yellow needle like crystals $(8.2 \mathrm{mg})$;

${ }^{1} \mathrm{H}$ NMR (300 MHz, $\mathrm{CDCl}_{3}$ ), $\delta_{\mathrm{H}}$ (m, $J$ in Hertz): 6.32

(s, H-4), 7.55 (brd, $J=9 \mathrm{~Hz}, \mathrm{H}-5), 7.77$ (ddd, $J=8.7,6.9$,

$1.8 \mathrm{~Hz}, \mathrm{H}-6$ ), 7.36 (m, H-7), 8.50(dd, J= 7.8, $1.5 \mathrm{~Hz}, \mathrm{H}-8)$,

3.89(s, N-CH 3 ), 3.98 (s, 1- $\left.\mathrm{OCH}_{3}\right), 4.07$ (s, 3- $\left.\mathrm{OCH}_{3}\right)$;

${ }^{13} \mathrm{C}$ NMR $\left(\overline{75} \mathrm{MHz}, \mathrm{CDCl}_{3}\right): \overline{156.2}(\mathrm{C}-1), 130.2(\mathrm{C}-2)$, 159.4 (C-3), 86.7 (C-4), 140.5 (C-4a), 114.6(C-5), 142.1(C-5a), 134.0 (C-6), 121.5(C-7), 126.7(C-8), 120.8 (C-8a), 180.7 (C-9), 105.9 (C-9a), 34.1(N-CH $\left.{ }_{3}\right)$, $60.8\left(1-\mathrm{OCH}_{3}\right), 56.0\left(3-\mathrm{OCH}_{3}\right)$; ESI-MS ([M]

${ }^{+}$at $m / z$ 285.4) calcd for $\overline{\mathrm{C}}_{16} \mathrm{H}_{15} \mathrm{NO}_{4}$

Compound 2: Yellow powder (7.2 mg); ${ }^{1} \mathrm{H}$ NMR (300 MHz, $\left.\mathrm{CDCl}_{3}\right), \delta_{\mathrm{H}}$ (m, $J$ in Hertz): 6.32(d, $J=2.1 \mathrm{~Hz}, \mathrm{H}-2), 6.54(\mathrm{~d}, J=2.2 \mathrm{~Hz}, \mathrm{H}-4), 7.25$ (m, H-5), 7.25 (m, H-6), 7.35 (m, H-7), 8.39 (dd, J=8.1, $1.6 \mathrm{~Hz}, \mathrm{H}-8), 3.93\left(\mathrm{~s}, \mathrm{~N}-\mathrm{CH}_{3}\right), 3.97$ (s, 3- $\left.\left.\mathrm{OCH}_{3}\right) ;{ }^{13} \mathrm{C} \mathrm{NMR} \mathrm{(75} \mathrm{MHz,} \mathrm{CDCl}_{3}\right): 165.3$ (C-1), 89.6 (C-2), 166.3 (C-3), 89.5 (C-4), 142.5 (C-4a), 115.4 (C-5), 145.0 (C-5a), 134.1 (C-6), 121.2 (C-7), 126.9 (C-8), 120.7 (C-8a), 180.4 (C-9), 104.8 (C-9a), $33.8\left(\mathrm{~N}-\mathrm{CH}_{3}\right), 55.2\left(3-\mathrm{OCH}_{3}\right)$; ESI-MS $\left([\mathrm{M}]^{+}\right.$at $\left.m / z 255.3\right)$ calcd for $\overline{\mathrm{C}}_{15} \mathrm{H}_{13} \mathrm{NO}_{3}$ Compound 3: Orange powder (5.0 mg); ${ }^{1} \mathrm{H}$ NMR $\left(300 \mathrm{MHz}, \mathrm{CDCl}_{3}\right), \delta_{\mathrm{H}}(\mathrm{m}, J$ in Hertz): 8.07(d, $J=9.6 \mathrm{~Hz}$, $\mathrm{H}-8), 7.64$ (d, $J=2.7 \mathrm{~Hz}, \mathrm{H}-4) 7.29$ (d, $J=9.6 \mathrm{~Hz}, \mathrm{H}-7$ ) $7.10(\mathrm{~d}, J=2.7 \mathrm{~Hz}, \mathrm{H}-2), 4.49\left(\mathrm{~s}, 5-\mathrm{OCH}_{3}\right), 4.17$ (s, 1-OCH3), 4.08 (s, N-H); ${ }^{13} \mathrm{C}$ NMR (75 MHz, $\mathrm{CDCl}_{3}$ ): 157.3 (C-1), 102.1 (C-2), 164.3 (C-3), 104.7

(C-4), 143.1 (C-4a), 141.4 (C-5), 142.0 (C-5a), 152.2

(C-6), 112.2 (C-7), 118.2 (C-8), 115.0 (C-8a), 185.1

(C-9), 104.7 (C-9a), 59.1 (1- $\left.\mathrm{OCH}_{3}\right), 61.7\left(5-\mathrm{OCH}_{3}\right)$, $56.9\left(6-\mathrm{OCH}_{3}\right)$

\section{Antimycobacterial activity of compounds}

Compound 1, 2 and 3 were screened for activity against M. tuberculosis. Compound 1 had MICs of $1.5 \mu \mathrm{g} / \mathrm{ml}$, $3.5 \mu \mathrm{g} / \mathrm{ml}$ and $8.3 \mu \mathrm{g} / \mathrm{ml}$ on the pan sensitive, isoniazid 


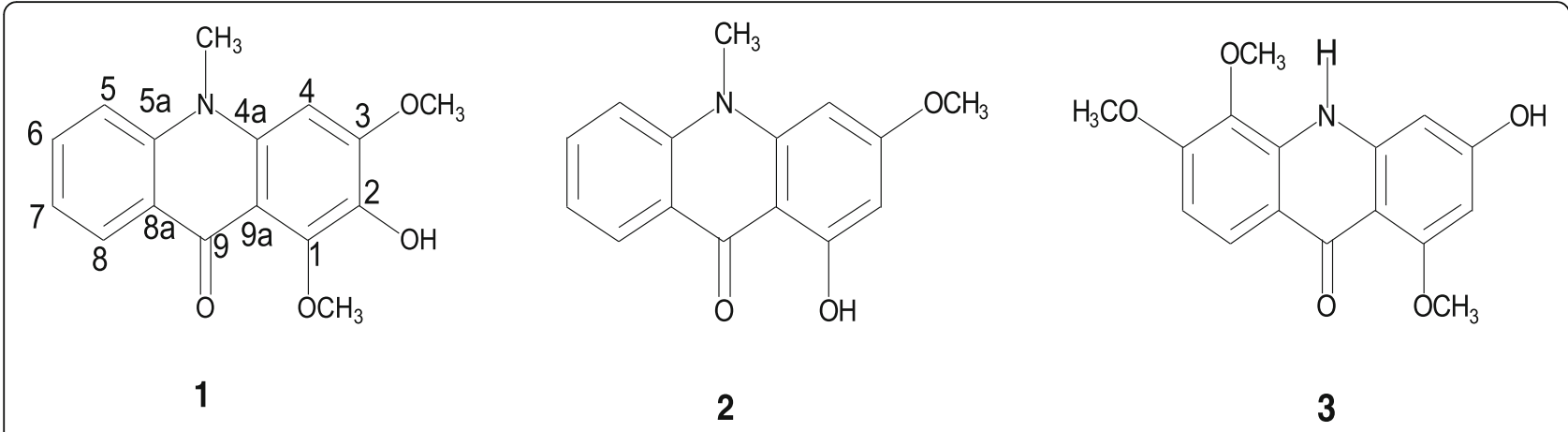

Fig. 1 Chemical structure of compounds 1,2 and 3

resistant and rifampicin resistant strains respectively (Table 2). Compound 3 had MICs of $5.1 \mu \mathrm{g} / \mathrm{ml}, 4.5 \mu \mathrm{g} /$ $\mathrm{ml}$ and $3.9 \mu \mathrm{g} / \mathrm{ml}$ on the pan sensitive, isoniazid resistant and rifampicin resistant strains of $M$. tuberculosis respectively while the MIC of compound 2 was beyond the tested concentration, $6.250 \mu \mathrm{g} / \mathrm{ml}$.

\section{Discussion}

$>$ The search for new anti TB drugs is continuing to be the focus for most research globally due to development of multi drug and extensively drug resistant strains of M. tuberculosis. Although drugs like bedaquiline and delamanid have recently been discovered and are used in treatment of MDR TB [7], they are equally expensive and unavailable in poor resource countries. Furthermore reports of totally drug resistant TB in countries like India and South Africa are threatening to make the disease untreatable $[16,17]$. In this study, the anti mycobacterial activity of the crude extracts, fractions and compounds from $Z$. leprieurii were evaluated to help demonstrate the plant's potential as an alternative source for new anti TB agents. The extracts/fractions were considered to be active if the MICs were $\leq 100 \mu \mathrm{g} / \mathrm{ml}[18,19]$ while the pure compounds were considered to have antimycobacterial activity if their MIC $\leq 6.25 \mu \mathrm{g} / \mathrm{ml}$; the maximum tested concentration. In the same way an extract, fraction or compound

Table 2 Mean MIC Values of isolated compounds 1, 2 and 3 on three strains of M. tuberculosis

\begin{tabular}{llll}
\hline \multirow{2}{*}{ Compound } & \multicolumn{3}{l}{ Antimycobacterial activity MIC $(\mu \mathrm{g} / \mathrm{ml})$} \\
\cline { 2 - 4 } & $\begin{array}{l}\text { Pan sensitive } \\
\text { strain (H37Rv) }\end{array}$ & $\begin{array}{l}\text { Rifampicin resistant } \\
\text { strain (TMC 331) }\end{array}$ & $\begin{array}{l}\text { Isoniazid resistant } \\
\text { strain (TMC 301) }\end{array}$ \\
\hline 1 & $1.5 \pm 0.8$ & $5.9 \pm 3.2$ & $3.2 \pm 1.7$ \\
2 & $>6.250$ & $>6.250$ & $>6.250$ \\
3 & $5.1 \pm 1.1$ & $4.1 \pm 0.0$ & $3.9 \pm 0.6$ \\
Isoniazid & $2.0 \pm 0.0$ & $4.0 \pm 2.1$ & - \\
Rifampicin & $4.0 \pm 0.0$ & - & $2.0 \pm 0.0$ \\
\hline
\end{tabular}

\pm Standard deviation was considered not to be active if the MIC value was beyond the tested concentration.

Both crude extracts from $Z$. leprieurii showed some inhibitory activity with the methanol extract being more active against all the $M$. tuberculosis strains as compared to the chloroform extract. This could be due to numerous compounds extracted by methanol which is believed to be an efficient solvent during extraction [20-22]. The methanol extract was fractionated and fractions $\mathrm{Za}_{4}$ and $\mathrm{Za}_{6}$ were the most active against all the tested strains; implying that they could possibly contain compounds which could be active on MDR TB warranting further phytopharmacological analysis. However, the activity of the crude extracts was generally lower than that of the pure drugs; isoniazid and rifampicin. The low anti-TB inhibition exhibited by the crude extracts could be due to presence of impurities which may interfere with and reduce the potency of the extracts [23]. Over all, purification of $Z$. leprieurii methanol extract yielded fractions that showed substantial activity than the crude extracts especially against the pan sensitive strain. Among these, fraction $\mathrm{Za}_{4}$ (MIC $=6.3 \mu \mathrm{g} / \mathrm{ml}$ ) was seven times more potent than the methanol crude extract $(\mathrm{MIC}=47.5 \mu \mathrm{g} / \mathrm{ml})$.

Three known acridone alkaloids that is; 2-hydroxy-1, 3-dimethoxy-10-methyl-9-acridone (1), 1-hydroxy-3methoxy-10-methyl-9-acridone (2) and 3-hydroxy-1, 5, 6-trimethoxy-9-acridone (3) were isolated from fractions $\mathrm{Za}_{4}$ and $\mathrm{Za}_{7}$. Their structures were confirmed by analyzing their spectral data and also through comparison with already published work [24-26]. When screened for anti mycobacterial activity, compound $\mathbf{1}$ was found to have a lower $\mathrm{MIC}$ value $(\mathrm{MIC}=1.5 \mu \mathrm{g} / \mathrm{ml})$ than both isoniazid $(\mathrm{MIC}=0.2 \mu \mathrm{g} / \mathrm{ml})$ and rifampin $(\mathrm{MIC}=0.4 \mu \mathrm{g} / \mathrm{ml})$; two first line drugs that form a backbone in TB treatment [27]. This shows that there is potential for further development of compound $\mathbf{1}$ into new anti TB agents that could be an alternative to the two most important first line drugs in TB treatment. On the contrary, Compound 2 was inactive on $M$. tuberculosis. The variation in activity could not be verified in this study however it is thought 
that it could be linked to the number and positions of hydroxyl and methoxy groups on rings A and B. Previous studies have shown that the antimycobacterial activity of alkaloids is affected by the number and positions of functional groups [28].

Previous studies done on Cameroonian spices revealed that Z. xanthoxyloides and Z. macrophylla showed weak activity with MICs of $1.024 \mathrm{mg} / \mathrm{ml}$ against $\mathrm{H} 37 \mathrm{Rv}$ and H37Ra [29]. However a study by Luo et al., [30] showed that extracts from $Z$. capense had antimycobacterial activity. In addition, decarine, a benzophenanthridine alkaloid was isolated and found to inhibit growth of $M$. tuberculosis within macrophages with MIC of $1.6 \mu \mathrm{g} / \mathrm{ml}$ on the pan sensitive strain. Compound $\mathbf{3}$ has been shown to have cytotoxic effects (IC50 of $86 \mu \mathrm{M}$ ) against liver cancer cell lines by inhibiting glycosyltransferase and aromatase enzymes in the liver [31]. In addition compound $\mathbf{2}$ had a moderate activity of 33\% mortality against Anopheles gambiae larvae at a concentration of $1000 \mathrm{ppm}$ [31]. In a review by Kishore et al., (2009) [32], different types of alkaloids have been shown to have anti mycobacterial activity however no study has reported activity of acridone alkaloids on resistant strains of TB. Our results add to other plant derived compounds from genus Zanthoxyllum which could be further explored as anti TB agents.

\section{Conclusion}

Our results show that Pharmacological assessment of $Z$. leprieurii could potentially lead to the discovery of new anti TB agents. Bioassay guided isolation of $Z$. leprieurii afforded three acridone alkaloids; two of which showed activity on $M$. tuberculosis resistant strains. These findings also provide some scientific evidence to support, to some extent, the ethnomedicinal use of $Z$. leprieurii as traditional antitubercular remedies in Uganda communities though more studies on the in-vivo antimycobacterial activity and toxicity of the bio active compounds is needed.

\section{Additional files}

Additional file 1: Figure showing one of the results as they were observed on microplate. (DOCX $421 \mathrm{~kb}$ )

Additional file 2: Figure showing purity of the isolated compounds as separated by TLC plates. (DOCX $124 \mathrm{~kb}$ )

Additional file 3: Proton NMR spectra of compounds 1, 2 and 3. (DOCX 208 kb)

\section{Abbreviations}

1D: One dimensional; 2D: Two dimensional; AIDS: Acquired immune deficiency syndrome; HIV: Human immune virus; JCRC: Joint clinical research centre; MABA: Micro plate alamar blue assay; MDR: Multi drug resistance; MIC: Minimum inhibitory concentration; NMR: Nuclear magnetic resonance; TB: Tuberculosis; TLC: Thin layer chromatography; WHO: World Health Organisation; XDR: Extensive drug resistance

\section{Acknowledgements}

We would like to thank all members from Joint Clinical Research Centre, in particular Sam Ogwang for all the advice they gave us while carrying out the bioassays. Also would like to acknowledge support of Colleagues from University of Botswana for all the technical advice they offered during isolation.

\section{Funding}

We acknowledge Carnegie cooperation through Next Generation of African Academics1 (NGAA1) and Regional Initiative in Science and Education -African Natural products Network (RISE-AFNNET), Commonwealth University Young Career award and Network for Analytical Bioassay Services in Africa (NABSA) for funding this work.

Availability of data and materials

All data has been provided in the paper.

\section{Authors' contributions}

$\mathrm{BL}$ collected the plants, was involved in the preparation of the extracts and bio-assay testing of crude extract, fractions and isolated compounds. GWF and BL were involved in the isolation, NMR and MS analysis as well as the structural elucidation of the isolated compounds and writing of the manuscript. SOY, PW and JT did the conception, sought for funding, supervised the work and corrected the final manuscript. All authors read the manuscript, contributed in correcting it, and approved its final version.

\section{Competing interests}

The authors declare that they have no competing interests.

\section{Consent for publication}

Not applicable.

\section{Ethics approval and consent to paticipate}

The research was approved by the Uganda National council of Science and Technology (HS 1288) and also by Makerere University College of Health sciences Institutional Review Board. Consent to participate: Not applicable.

\section{Author details}

${ }^{1}$ Department of Pharmacology and Therapeutics, College of Health Sciences, Makerere University, P.O Box 7072, Kampala, Uganda. ²Department of Organic Chemistry, Faculty of Science, University of Yaoundé I, P.O Box 812, Yaoundé, Cameroon. ${ }^{3}$ Department of Environmental management, Makerere University, P.O. Box 7062, Kampala, Uganda. ${ }^{4}$ Department of Chemistry, Faculty of Science, University of Botswana, Private Bag UB00704, Gaborone, Botswana.

Received: 8 October 2016 Accepted: 25 January 2017

Published online: 02 February 2017

\section{References}

1. World Health Organization. Global tuberculosis report. Geneva: WHO Report; 2015.

2. World Health Organisation: Tuberculosis fact sheet. www.who.int/tb/ publications/factsheets; 2/9/2016

3. Wynne A, Richter S, Banura L, Kipp W. Challenges in tuberculosis care in Western Uganda: Health care worker and patient perspectives. Int J Nurs Stud. 2014:1:6-10.

4. Sarathy JP, Dartois $V$, Lee EJD. The role of transport mechanisms in Mycobacterium tuberculosis drug resistance and tolerance. Pharmaceuticals. 2012;5:1210-35.

5. Phillips $L$. TB's revenge, the world is starting to win the war but drug resistant forms pose a new threat. Nature. 2013;493:14-6.

6. Sotgiu G, Ferrara G, Matteelli A, Richardson MD, Centis R, Ruesch-Gerdes S, Toungoussova O, Zellweger J-P, Spanevello A, Cirillo D, Lange C, Migliori GB. Epidemiology and clinical management of XDR-TB: a systematic review by TBNET. Eur Respir J. 2009:33:871-81.

7. Cox E, Laessig K. FDA approval of Bedaquiline- the Benefit-Risk Balance for Drug-Resistant Tuberculosis. New Eng J of Med. 2014;371:689-91.

8. Zia-u1-Haq M, Riaz M, Saad B. Anthocyanins and human health: Biomolecular and therapeutic aspects. Springer international publishing; 2016. http://www springer.com/us/book/9783319264547. 
9. Chin YW, Balunas MJ, Chai HB, Kinghorn AD. Drug discovery from natural sources. AAPS Pharm Sci Tec. 2006;8:239-53.

10. Patiño Ladino OJ, Cuca Suárez LE. Chemical constituents of the wood from Zanthoxylum quinduense Tul. (Rutaceae). Quím. 2010;33:1019-21.

11. Harmill HM. The useful plants of West tropical Africa. 2nd ed. Kew: Royal Botanical Gardens; 1997.

12. Lamorde M, Tabuti JRS, Obua C, Kukunda-Byobona C, Lanyero H, Byakika-Kibwika P, Bbosa GS, Lubega A, Ogwal-Okeng J, Ryan M, Waako PJ, Merry C. Medicinal plants used by traditional medicine practitioners for the treatment of HIV/AIDS and related conditions in Uganda. J Ethnopharmacol. 2010;130:43-53.

13. Bunalema L, Obakiro S, Tabuti JR, Waako P. Knowledge on plants used traditionally in the treatment of tuberculosis in Uganda. J Ethnopharmacol. 2014;15:999-1004

14. Tabuti JR, Kukunda CB, Waako PJ. Medicinal plants used by traditional medicine practitioners in the treatment of tuberculosis and related ailments in Uganda. J Ethnopharmacol. 2010;127:130-6.

15. Lawal TO, Adeniyi BA, Wan B, Franzblau SG, Mahady. In Vitro Susceptibility of Mycobacterium tuberculosis to extracts of Uvaria afzelli and Tetracera alnifolia. Afr J Biomed Res. 2011;14:17-21.

16. Migliori GB, Sotgiu G, Gandhi NR, Falzon D, DeRiemer K, Centis R, Hollm-Delgado MG, Palmero D, Pérez-Guzmán C, Vargas MH, D'Ambrosio L, Spanevello A, Bauer M, Chan ED, Schaaf HS, Keshavjee S, Holtz TH, Menzies D. Drug resistance beyond XDR-TB: results from a large individual patient data meta-analysis. Eur Respir. 2012;42:169-79.

17. Udwadia ZF, Amale RA, Ajbani KK, Rodrigues C. Totally Drug-Resistant Tuberculosis in India. Clin Infect Dis. 2012;54:579-81.

18. Cos P, Vlietinck AJ, Berghe DV, Maes L. Anti-infective potential of natural products: how to develop a stronger in vitro 'proof-of-concept. J Ethnopharmacol. 2006;106:290-302.

19. Gautam R, Saklani A, Jachak SM. Indian medicinal plants as a source of antimycobacterial agents. J Ethnopharmacol. 2007;110:200-34.

20. Cowan MM. Plant products as antimicrobial agents. Clin Microbiol Rev. 1999;12:564-84

21. Do QD, Angkawijaya AE, Tran-Nguyen PL, Huynh LH, Soetaredjo FE, Ismadji S, Ju Y-H. Effect of extraction solvent on total phenol content, total flavonoid content, and antioxidant activity of Limnophila aromatica. J Food Drug Anal. 2014;22:296-302.

22. Chatha SAS, Anwar F, Manzoor M, Bajwa JR. Evaluation of the antioxidant activity of rice bran extracts using different antioxidant assays. Grasas Aceites (Sevilla). 2006;57:328-35.

23. Akintola AO, Kehinde AO, Adebiyi OE, Ademowo OG. Anti-tuberculosis activities of the crude methanolic extract and purified fractions of the bulb of Crinum jagus. Niger J Physiol Sci. 2013;28:135-40.

24. Hughes GK, Neill KG. Alkaloids of the Australian Rutaceae: Evoxia xanthothyloides. Aust J Biol Sci. 1949;2A:429-36.

25. Ngoumfo RM, Jouda JB, Mouafo FT, Komguem J, Mbazoa CD, Shiao TC, Choudhary MI, Laatsch H, Legault J, Pichette A, Roy R. In vitro cytotoxic activity of isolated acridones alkaloids from Zanthoxylum leprieurii Guill. et Perr. Bioorg Med Chem. 2010;18:3601-5.

26. Wouatsa VNA, Misra L, Kumar S, Prakash O, Khan F, Tchoumbougnang F, Venkatesh RK. Aromatase and glycosyl transferase inhibiting acridone alkaloids from fruits of Cameroonian Zanthoxylum species. Chem Cent J. 2013;7:125.

27. Sloan DJ, Lewis JM. Management of multidrug-resistant TB: novel treatments and their expansion to low resource settings. Trans R Soc Trop Med Hyg. 2016;110:163-72.

28. Yadav AK, Thur J, Prakash OM, Khan F, Saikia D, Gupta MM. Screening of flavonoids for antitubercular activity and their structure-activity relationships. Med Chem Res. 2013;6:2706-16.

29. Tekwu EM, Askun A, Kuete V, Nkengfack AE, Nyasse B, Etoa F, Beng P. Antibacterial activity of selected Cameroonian dietary spices ethnomedically used agnaist strains of Mycobacterium tuberculosis. J Ethnopharmacol. 2012;142:374-82.

30. Luo X, Pires D, Aínsa JA, Gracia B, Duarte N, Mulhovo S, Anes E, Ferreira MJ. Zanthoxylum capense constituents with antimycobacterial activity against Mycobacterium tuberculosis in vitro and ex vivo within human macrophages. J Ethnopharmacol. 2013;146:417-22.

31. Matasyoh JC, Talontsi FM, Ngoumfo RM, Chepkorir R. Larvicidal activity of acridone alkaloids from Zanthoxylum leprieurii against the malaria vector Anopheles gambiae. J Nat Prod. 2011;1:121-4.

32. Kishore N, Mishra BB, Tripathi V, Tiwari VK. Alkaloids as potential anti-tubercular agents. Fitoterapia. 2009;80:149-63.

\section{Submit your next manuscript to BioMed Central and we will help you at every step:}

- We accept pre-submission inquiries

- Our selector tool helps you to find the most relevant journal

- We provide round the clock customer support

- Convenient online submission

- Thorough peer review

- Inclusion in PubMed and all major indexing services

- Maximum visibility for your research

Submit your manuscript at www.biomedcentral.com/submit
Biomed Central 